\title{
PALATALIZATION IN WEST CHADIC
}

\author{
Russell G. Schuh \\ UCLA
}

Morphological palatalization is a phenomenon whereby palatal articulation (fronting of vowels, adding palatalization as a secondary articulation to consonants, changing alveolars to alveopalatals) is a property associated with an entire morpheme, not with individual segments. Within the Chadic language family, morphological palatalization is best documented in the Biu-Mandara branch, but it has been inherited as a feature in the West branch as well. This paper explores palatalization phenomena in the West Branch that conceivably trace their origin to morphological palatalization. In Miya, morphological palatalization operates much as it does in Biu-Mandara languages, affecting entire morphemes and associating with specific morphological processes. Duwai exhibits remnants of morphological palatalization in certain verb alternations. Bole shows alveolar/alveopalatal variations in specific lexical items that have no local phonological explanation. In Hausa, the origin of palatal consonants has long been a source of controversy. The paper argues that local phonological processes of palatalization cannot account for a large number of the palatals in modern Hausa, a claim that has implications for the analysis of the system of high vowels.

\section{Morphological Palatalization}

Many languages in the Biu-Mandara branch of the Chadic family ${ }^{1}$ have a phenomenon which I will refer to as "morphological palatalization". Carl Hoffmann was apparently the first person to describe this phenomenon, writing about Gude in Hoffmann [1972], 2 a paper which I have not seen, cited in Hoskison [1975:5], but the phenomenon is now well-described for a number of other Biu-Mandara languages. Rather than a local effect whereby, say, $s$ palatalizes to $\breve{s}$ before a front vowel, morphological palatalization affects a whole word. Typical is the situation in

1 Newman [1977], in the classification followed here, proposes four major branches in the Chadic family: West, comprising languages spoken in northern Nigeria; Biu-Mandara, comprising languages spoken in northeastern Nigeria and northern Cameroon; Masa, comprising languages spoken in southwestern Chad, extending into eastern Cameroon; and East, comprising languages in western and central Chad.

2 The title of Hoffmann's paper refers to "Mapuda" [mapuda], a now archaic autonym of the Gude [Hoskison 1975:4]. 
Podoko, for which Swackhamer [n.d.] says, "Palatalization works as a word level prosody. It affects the central vowels, causing /a/ to be realized as $[\varepsilon]$ and /a/ to be realized as [i]. It affects the alveolar consonants, especially the fricatives, and in some environments, the stops and the nasal $/ \mathrm{n} /$." Thus, for example, the nonpalatalized root /baza/ 'to unearth' is pronounced [baza], but its imperative, which is palatalized, is pronounced [bežc].

In these languages, it is clear that morphological palatalization is a word level phenomenon rather than a phoneme-level alternation because, first, it affects a word globally, shifting pronunciation of both consonants and vowels, and second, though it potentially affects all the segments of a word, it is often variable in the extent to which it affects specific segments. Hoskison [1975:41] gives the following routine for palatalizing the root consonants of the Gude VENTIVE form of the verb (called "MOTION-TO-SPEAKER" by Hoskison), which consists of changing the stem final vowel to $/ \mathrm{a} /$ and palatalizing the word:

- Obligatorily change /d, n, s, z, ts, dz/ to their palatal counterparts ['y, ñ, $\breve{s}, \check{z}, \breve{c}, \breve{j}]$.

- If the root has none of the consonants above but it does contain one or more other coronals, then palatalize at least one of those.

- If the root contains no coronals, then palatalize at least one other consonant other than $/ \mathrm{y} /(/ \mathrm{\gamma} /$ is not palatalizable, but no roots contain only $/ \gamma /$ ).

- Optionally palatalize any consonant in addition to the obligatory palatalizations above.

For example, the verb /sàba/ 'drive away' has a "neutral" verbal noun [sàbán] and a ventive verbal noun [š̀bán], with obligatorily palatalized [̌̌] but unpalatalized [b]. ${ }^{3}$ The "neutral" verbal noun of /táł/ 'sew' is [táłán], whereas the ventive verbal noun is [tílyán], with the medial lateral fricative palatalized, but not the initial /t/. The neutral verbal noun of /də̀m/ 'enter' is [də̀mə̀ná], whereas the ventive is [gyìmán], with the coronal $/ \mathrm{d} /$ palatalized to $[\mathrm{g} y$ ] but the labial $/ \mathrm{m} / \mathrm{not}$ palatalized. The root /6ª́/ 'sip', with only a labial consonant has neutral verbal noun [ $6^{w}$ ún] but ventive [6Чén]. Note that morphological palatalization also affects vowels. Hoskison, writing in a linear framework, described changes in vowels as assimilations to neighboring palatalized consonants, but if one views morphological palatalization as a word level prosodic pattern, there is no reason to give the consonants priority.

Morphological palatalization in Biu-Mandara languages functions both as a feature of certain morphosyntactic processes, such as the Podoko imperative or the Gude ventive, and as an unpredictable lexical feature of certain words. Swackhamer [n.d.] cites pairs of words such as [patsa] 'sun' vs. [petšs] $(=/$ patsa/ + palatalization) 'g-string' or [vula] 'bedbug' vs. [vul $\varepsilon](=/ \mathrm{vula} /+$ palatalization $)$ 'mollusk'. Gude has pairs such as [hòná] 'to shoot' (cf. palatalized perfective form [hy $\left.\left.y_{1}\right]\right)$ vs. [hyin] 'millet'.

3 Examples are from my own notes on Gude, which I worked on for about a year and a half in the late 1970's. 
Although morphological palatalization is fairly well described for a number of Biu-Mandara languages, as far as I know, no one has done any comparative work specifically on palatalization, such as reconstructing certain roots as palatalized and others as non-palatalized or reconstructing particular morphological processes as incorporating palatalization. In fact, the morphological processes associated with palatalization differ from language to language, e.g., in Podoko, verbs in the imperfective are palatalized [Jarvis n.d.:42ff.], whereas in Gude, verbs in the perfective (= completive) are palatalized [Hoskison 1983:83ff.], making it unclear whether we are dealing with analogous processes or true homologs. Despite our current ignorance about comparative aspects of morphological palatalization, it seems likely that this must be reconstructed as a feature of Biu-Mandara. It is too widespread and too systematic among languages that are not particularly closely related and not in contact with each other to be a result of either accidental convergence or areal spread.

The hypothesis that morphological palatalization was a feature of proto-BiuMandara raises the question of whether it might be a feature inherited from an even deeper historical level. This paper will suggest that there is evidence that the answer to this question is, "Yes," at least to the level of the shared ancestor of BiuMandara and West Chadic. No West Chadic language so far described has morphological palatalization of the systematic and productive nature found in some Biu-Mandara languages. However, at least one West Chadic language, Miya, does have palatalization that works as a word level prosody, much as in Biu-Mandara languages, and if one once thinks of morphological palatalization as having been a feature of proto-West Chadic, a number of apparent anomalies in other languages seem less of a puzzle. I will begin by briefly summarizing the situation in Miya. Next I look at the Bade/Ngizim group, especially Duwai, where certain alternations and other facts are reminiscent of morphological palatalization. Along with Miya, these languages all belong to Newman's [1977] "B" sub-branch of West Chadic. Languages of Newman's "A" sub-branch of West Chadic, which includes Hausa, ${ }^{4}$ also have what may be remnants of morphological palatalization. In West Chadic "A", I begin by examining Bole, which has a rather "fluid" phonology, especially in the coronal area, and I finally turn to Hausa and the vexed question of whether the contrasts between words such as tunyà 'cactus' vs. cinyà 'thigh' reside in the consonants or the vowels.

\section{Miya $^{5}$}

In this section, I briefly summarize the description of Miya morphological palatalization in Schuh [1998:33-36]. The phonetic effects of morphological palatalization in Miya, a West Chadic "B" language of the North Bauchi subgroup, are essen-

4 Recent comparative work that I have been doing on West Chadic has caused me to question a close relationship between Hausa and other languages now considered West Chadic " $A$ ". There is no question of the West Chadic affiliation of Hausa, however, and its exact place within West Chadic would have no implications for the phenomena discussed in this paper.

5 Field work on Miya in 1982-83 was supported by a grant from the Wenner-Gren Foundation for Anthropological Research. 
tially identical to those in Biu-Mandara languages. In a word with morphological palatalization,

- the [+delayed release] coronals /ts, dz, s, z/ are obligatorily realized as the palatal counterparts $[\mathrm{c}, \mathrm{j}, \mathrm{sh}, \mathrm{zh}] ; 6$

- other consonants are optionally palatalized;

- /ə/ is almost always realized as [i] in word final position and frequently in word medial position as well;

- $/ a /$ is often realized as $[\varepsilon]$ (written " $e$ " here-see footnote);

- /ā/ is usually realized as [ǣ]

As in the Biu-Mandara languages, these effects are somewhat variable from word to word and in repetitions of the same word. In (1) are a few palatalized words, written as I recorded them in my notes. The form between slashes is the segmental form without palatalization.
(1) títelúw /tátalúw/ 'type of flute' éryúw lárúw/ 'pus' tyámátyam /támátam/ 'stench' mbyæédlí /mbấdlá/ 'cucumber' ázhìpiy láż̀pəy/ 'tears' ávyấdi lávấdə/ 'buttocks'

Also as in Biu-Mandara languages, palatalization is a lexical feature of some words and morphemes but not of others, though lexically palatalized words are very much in the minority [Schuh 1998:35]. There are minimal pairs segmentally distinguished only by palatalization, as in (2), for example.
(2)

$\begin{array}{ll}\text { mòr } & \text { 'sesame' } \\ \text { átóm } & \text { 'song' } \\ \text { làbado } & \text { 'shoulder' }\end{array}$
mir 'money'
átím 'nose'
lébedi a type of basket

Miya differs from Biu-Mandara languages in that morphological palatalization is no longer a productive part of any morphological process. There are, however, a few areas of morphology where a single root may have contrastive palatalized and non-palatalized alternants. The morphological pairing which best illustrates this is verb vs. derived verbal noun. For a number of verbs, the root form is not palatalized but the derived verbal noun is, as in (3).

\footnotetext{
6 Here and elsewhere I will use the following orthographic conventions: $c=[\mathrm{t} f], j=\left[\mathrm{d}_{3}\right], s h=$ [ $\left.\int\right], z h=[3], t l=[1], d l$ in Miya and $j l$ in Bade $=[3]$. A palatal co-articulation of consonants other than these will be represented by a $y$ following the consonant, e.g., $g y=\left[g^{y}\right]$. The vowel a $=[\mathrm{i}]$. Medially, the short vowels which I will symbolize as $i, u, e$ tend to have a lax pronunciation, phonetically more like [I, $v, \varepsilon]$. A macron over a vowel represents a long vowel, though in Miya, I represent phonetic [i:] and [u:] as $i y$ and $u w$, respectively (see Schuh [1998:20-22] for discussion). Grave accent indicates low tone. In Miya, acute accent on a domain initial syllable = high tone. Elsewhere in Miya and Bade, acute accent = downstepped high. In Miya, syllables unmarked for tone retain the tone of the nearest syllable to the left. In other languages, unmarked syllables bear high tone.
} 


\section{(3) zəza 'flay' but ázhózhə 'flaying' \\ tloma 'shave' átlyám 'shaving'}

(cf. tsəga 'sit', átságə ‘sitting' without palatalization)

rəvəzə 'be fat' but ràvazhi 'fatness'
'əsə 'be sated'

(cf. tənsə 'itch', tàmasə 'itching' without palatalization)

See Schuh [1998:36] for a few other areas where palatalization plays a morphological role, albeit a frozen, lexicalized one.

\section{Duwai, Bade, and Ngizim?}

Duwai, Bade, and Ngizim are three fairly closely related languages of the "B" branch of West Chadic. They are thus first cousins of Miya within West Chadic "B", in contrast to their more distant cousins in the "A" branch of West Chadic, such as Bole and Hausa. Bade and Ngizim are particularly closely related, and in fact, impressionistically, Ngizim resembles the Gashua dialect of Bade more than that dialect resembles other Bade dialects, suggesting that some features shared across Bade but not shared by Ngizim may be the result of areal diffusion rather than shared inheritance (see Schuh [1981] for discussion of Bade dialects). Duwai, on the other hand, is quite distinct from its sisters and clearly represents a separate branch within this group. Bade is dialectally diverse [Schuh 1981] and Duwai appears to be so, though I have little systematic information on Duwai dialects.

Looking at any of these languages purely on internal grounds, one would probably not propose processes of morphological palatalization like those described above for Biu-Mandara languages or Miya. Both Duwai and Ngizim have a productive rule that changes alveolar consonants other than lateral fricatives, $l$, and $r$ to their palatal counterparts when an $-i$ follows, such as in the examples in (4), contrasting verbs in the perfective in each language with the subjunctive in Duwai and the singular imperative in Ngizim.

This rule is NOT shared by any dialect of Bade (cf. Gashua Bade màsu '(he) bought', amasí 'buy!'). Since Bade and Ngizim comprise a genetic subgroup separate from Duwai, Duwai and Ngizim must have developed locally conditioned palatalization of alveolars independently and fairly recently rather than having inherited it as a regular process from a common ancestor. Palatalization of alveolars before front vowels is, of course, a natural and widespread process in the world's languages, but it would be a remarkable coincidence if two closely related

7 Data from Ngizim comes primarily from work in a comparative Chadic syntax project in 196970, supported by a National Science Foundation Grant (GS-2279, Paul Newman, Principal Investigator). Data on Duwai and Bade come from two years field research when I was a Senior Research Fellow in the Centre for the Study of Nigerian Languages of Ahmadu Bello University (Paul Newman, Centre Director). 
(4) Phonologically conditioned palatalization in Duwai and Ngizim

\begin{tabular}{|c|c|c|}
\hline \multicolumn{3}{|c|}{ Duwai } \\
\hline Perfective & Subjun & \\
\hline òfto & àfci & 'lie down' \\
\hline kà̀do & $k \grave{a} j i$ & 'bite' \\
\hline kìdo & $k \overline{i ̀}^{\prime} y i$ & 'eat meat' \\
\hline mà̀so & mầshi & 'buy' \\
\hline tùzo & tùzhi & 'tip to pour' \\
\hline wà̀no & wằnyi & 'milk' \\
\hline
\end{tabular}

\begin{tabular}{|c|c|c|}
\hline \multicolumn{2}{|c|}{ Ngizim } & \\
\hline Perfective & Imperati & \\
\hline ràptu & 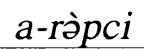 & 'open' \\
\hline zì̀du & $\grave{a}-z \bar{i} j i$ & 'slaughter' \\
\hline kìdu & à-kî'yi & 'eat meat' \\
\hline kà̀su & à-kāshi & 'sweep' \\
\hline b̀̀zu & a-bòzhi & 'leave' \\
\hline tànu & à-tānyi & 'remember \\
\hline
\end{tabular}

languages would independently initiate this process and, moreover, initiate it for exactly the same set of consonants (a set which differs from that of their distant cousin, Hausa, which palatalizes only $s, z, t$, and to a lesser extent $d$-see below). I will suggest that the seeds of the process already existed in proto-Duwai/ Bade/Ngizim and that the convergent innovation was not to initiate palatalization, but to "focus" it in the form we see it today.

In addition to this process of phonologically conditioned palatalization, Duwai has a process which is more like that of the morphologically conditioned palatalizations of some Biu-Mandara languages. Some, but not all verbs palatalize the root final consonant in the perfective but not in other TAM's (root final alveolars will, of course, palatalize in TAM forms that end in $-i$ by the general phonological rule illustrated in (4) above). The table in (5) illustrates verbs in their perfective and imperfective forms. In some of the examples, both perfective and imperfective have phonetically identical endings [-uwo], but they are underlyingly different. The perfective comes, historically, from *-ə-w(u), and is realized as final $-u$ in Bade and Ngizim, e.g., Ngizim r̃èttu 'divide', dàbu 'erect'. In Duwai, the perfective comes out as -ùwo if the final consonant of the verb is a palatal or a labial (a strange natural class!), e.g., rè̀ cùwo 'divide', d’̀bùwo 'erect', and as -o elsewhere, e.g., nùto 'pass' (cf. Ngizim nùtu 'pass'). The imperfective comes, historically, from *-a-w(u), e.g. Ngizim r̃èttaw 'will divide', ḋ̀baw 'will erect'. In Duwai, the -a 
becomes -ə if not phrase final, and assimilates to the $-w$ suffix to become [u]. ${ }^{8}$ In my list of 380 Duwai verbs, there are none with palatalized labials, palatalized liquids, or palatalized lateral fricatives.

(5) Duwai verbs with palatal consonant in the perfective

\begin{tabular}{|c|c|c|}
\hline Perfective & Imperfective & \\
\hline r̂̀̀̀cùwo & r̃ētùwo & 'divide' \\
\hline ̀̀bjùwo & àbdùwo & 'greet' \\
\hline pòkshùwo & poksà & 'postpone' \\
\hline gùzhgùzhùwo & guzgùzùwo & 'teach, learn' \\
\hline ว̀gvàdyùwo9 & ว̀gvàdù & 'rot, spoil' \\
\hline kə̀nyùwo & kə̀nò & 'spend the day' \\
\hline ว̀ckyùwo & ว̀ckùwo & 'cut in two' \\
\hline ว̀dgyùwo & ว̀dgù & 'become aware' \\
\hline
\end{tabular}

Palatalization of Duwai perfective verbs differs in important respects from BiuMandara languages where palatalization plays a morphological role. First, as described in sections 1 and 2, palatalization in Biu-Mandara and Miya is a word level prosody. In Duwai, palatalization in the perfective affects only the root final consonant. Second, unlike Biu-Mandara languages, where morphological palatalization is a fixed part of marking particular TAM's, palatalization of verbs in the perfective in Duwai is lexically specific and applies to only a minority of verbs. The table in (6) gives figures for the number of verbs in my data that do and do not alternate.

In addition to these systematic alternations associated with particular phonological or morphological environments, languages of the Duwai/Bade/Ngizim group show apparently unsystematic differences in (non-)palatalization in cognate lexical items. The table in (7) gives a sample. I have included Miya where a cognate is available.

8 The $-w(u)$ of the perfective and imperfective also have different origins. The perfective probably comes from a perfective marker *-ku, seen, for example in Bole-Tangale languages such as Kirfi shan-kò 'he lay down'. The imperfective is from a definite determiner *ku, still heard with the stop in Duwai imperfectives in the Dadigir dialect for verb forms ending in a voiceless consonant, e.g., yì đəb̀̀t-ko 'I will sell (it)'.

9 Note that the phonetic realization of / $d /$ under perfective palatalization is [dy], an alveolar with palatal co-articulation, where / $d /$ palatalized by a following $-i$ is [' $y$ ], a true palatal with glottal articulation. I would want to check this with a range of speakers over a range of tokens before asserting that this is a consistent distinction, however. 
(6) Numbers of Duwai verbs with and without alternating consonants

\begin{tabular}{|l|l|l|l|}
\cline { 2 - 4 } \multicolumn{1}{c|}{} & Alternate & Only non-palatal & Only palatal \\
\hline$t / c$ & 49 & 37 & 1 (only the monoverb cùwo 'beget') \\
\hline$d / j$ & 4 & 16 & 0 \\
\hline$s / s h$ & 1 & 13 & 2 (includes 1 monoverb shùwo 'lift') \\
\hline$z / z h$ & 1 & 1 & 0 \\
\hline$d / d y$ & 5 & 32 & 0 \\
\hline$n / n y$ & 6 & 23 & 1 (only the monoverb nyùwo 'bathe') \\
\hline$k / k y$ & 1 & 18 & 0 \\
\hline g/gy & 1 & 14 & 1 (the verb 'know'-see (7) below) \\
\hline
\end{tabular}

(7) West Chadic "B" palatal/alveolar correspondences

\begin{tabular}{|c|c|c|c|c|}
\hline Duwai & Ngizim & $\begin{array}{l}\text { Bade } \\
\text { (Western) } 10\end{array}$ & Miya & \\
\hline ìje & jă & jān & 'íy & 'dog' \\
\hline zhìmen & zòmànu & zìyàmən & & 'ostrich' \\
\hline kàshèn & gàzhàn & àgzànən & gùzəm & 'Nile monitor' \\
\hline shishî & (gəzhăw) & sasakon & áshúwashúw & 'star' \\
\hline $\begin{array}{l}\text { j̀mish } \\
\text { (cf. gòmso 'laugh') }\end{array}$ & gàmas & gà̀màsən & ghàmatsə & 'laughter' \\
\hline shirì & shirin & sərən & tsə̀r & 'two' \\
\hline zhìyà & zhà & zìyān & & 'war' \\
\hline İshau & shau & son & & 'excrement' \\
\hline àzgyàwo & zògau & ̀̀zgo & & 'know' \\
\hline dău & juwâk & jùwān & átiwìy & 'fly' \\
\hline
\end{tabular}

The point of these examples is to show cross-language variation in palatalization in roots which does not seem to have a phonological explanation. In these examples, and in general, Duwai has more palatal consonants lexically than do Bade and Ngizim. Bade appears to have undergone DEpalatalizatiion of *sh and *zh. In the list here, the word for 'star' is not only palatalized in Duwai and probably Ngizim (it is not clear exactly how to relate the Ngizim word to the others), but also in Miya. Depalatalization as a process in Bade is evident in borrowed words where words in the source language must have had palatals, e.g., Bade sə̀nkāfấn 'rice', 
probably from Hausa shìnkāfā. Bade has no words with $s h$ or $z h$, but it does have

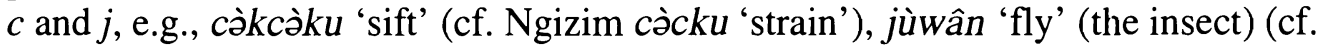
Ngizim juwâk). The word for 'fly' is of interest because it is NOT palatalized in Duwai, though it is in Miya, as the vowels indicate (assuming the Miya word is cognate - the $d \sim t$ correspondence is problematic).

Of particular interest are words where Duwai has both a palatal consonant and a vowel $e$, as in the words 'dog', 'ostrich', 'Nile monitor' in (7). Evidence points against reconstructing mid vowels for early stages of Chadic in general and for West Chadic " $B$ " in particular. In West Chadic " $B$ " languages, virtually all mid vowels transparently come from monophthongization of the diphthongs $a i$ and $a u$, from borrowings, and, relevant to this study, from palatalization of $a$. Thus, in a word like kìshèn 'Nile monitor', we cannot use -e- to explain the palatal sh if *e is not a reconstructable phonemic vowel, and we cannot explain $s h$ as conditioning a change $* \mathrm{a}>e$ because the original consonant was *z (cf. the Bade word and Miya gùzom-I do not, at the moment, have an explanation for devoicing of the consonant in Duwai). If, however, we assume that this group of languages inherited morphological palatalization as a non-productive, but still present phenomenon, something like what we see in Miya today, we can explain these facts. The different languages have frozen the original word prosody as lexicalized palatal segments in certain words and/or have converted it to a local phonologically conditioned change, as illustrated in (4) for Duwai and Ngizim. Only Duwai preserves more active remnants of the earlier system with palatalization of a subset of verbs in the perfective and in the related pair gəmso 'laugh', ̀̀mish 'laughter', a verb/verbal noun pair like those in Miya. 11

To conclude this section, consider the historical derivations in (8) of a pair of words which, by the hypotheses here, differed only in the presence or absence of morphological palatalization at the proto-Duwai/Ngizim/Bade level.

\begin{tabular}{|c|c|c|c|c|}
\hline & \multicolumn{2}{|c|}{ *àdà 'eye' } & \multicolumn{2}{|c|}{$*_{\text {ว̀da }}[+$ pal] $]$ 'dog' } \\
\hline & Duwai & Ngizim & Duwai & Ngizim \\
\hline $\begin{array}{l}\text { Palatalization } \\
\text { (proto-D/Ng/B) }\end{array}$ & NA & NA & ìje & ìje \\
\hline $\mathrm{B} / \mathrm{Ng}$ initial $\mathrm{V}$ loss & NA & dà & NA & jě \\
\hline Duwai V lengthening & ìdà & NA & ìje & NA \\
\hline $\begin{array}{l}\text { Loss of MP as a } \\
\text { prosody }\end{array}$ & (ì̀dà) & (dà) & (ije) & jă \\
\hline Modern form & ìdà & dà & ìje & jă \\
\hline
\end{tabular}

11 A detailed study of Duwai would probably reveal more lexicalized pairs such as this, but I have not yet come across any in my rather limited data. 


\section{REMARKS:}

(1) These words are cognate with Bole ìdo 'eye' and àdà 'dog', respectively. The initial a- of Bole 'dog' must result from assimilation of $*_{\partial}$ - to the final $-a$. At this time I have no explanation for the final $-o /$-a correspondence for 'eye'. 'Dog' is likewise cognate with Miya 'íy. In the North Bauchi languages, of which Miya is a member, non-initial $*_{\mathrm{d}}$ and $*_{\mathrm{t}}$ have fairly regularly changed to $y$ (cf. Miya miy 'die' vs. Bole motu, Miya kìyim 'crocodile' vs. Bole kadàm), and in Miya, all original word final vowels in monomorphemic words have been apocopated.

(2) $\mathrm{B} / \mathrm{N}$ initial V loss: Initial *ə- in open syllables has regularly been lost in Bade and Ngizim, a shared innovation which groups these languages as distinct from Duwai. This is probably not really a sound change, but rather a historical reinterpretation. Throughout this language group, vowels in hiatus coalesce, e.g., Bade /aci ว̀kfu/ $\rightarrow$ [acəkfú] 'he entered'. At an earlier stage, in an utterance such as */kùbə ̀̀dà/ $\rightarrow$ [kùbədà] '(he) closed (his) eye', the underlying form of 'eye' would have been ambiguous between /əda/ or simply /da/. The immediate ancestor language to Bade and Ngizim selected the latter interpretation across the board for such words—cf. also Duwai ìshau vs. Ngizim shau, Bade son in table (7).

(3) Duwai V lengthening: Duwai has regularly lengthened "real" vowels in nonfinal open syllables, where by "real" I mean non-epenthetic vowels, i.e., vowels whose presence and quality are not predictable on the basis of syllable structure. This affected both medial vowels, e.g., Duwai mầso 'buy' (cf. Bade màsu), and initial vowels, e.g., Duwai àzhòmòk 'Acacia seyal' (cf. Bade azว̀mān). Lengthened initial *ə > [i] in Duwai, possibly also a remnant of palatalization because, like many Chadic languages, Duwai does tolerate phonetic long [ə̄].

(4) Loss of MP as a prosody: The palatalized variant of $/ a /$ in languages with morphological palatalization is usually $[\varepsilon]$ (see fn. 6), but /a/ in palatalized words often does not undergo perceptible fronting (see a number of the examples in the section on Miya). Once Bade and Ngizim lost morphological palatalization as a word level prosody, the vowel /a/ emerged in its canonical phonetic realization. In Duwai, assuming we do not want to say that it has true morpholological palatalization, *a seems to have been phonologized as a front vowel, written " $e$ " here, in words that originally had prosodic palatalization.

\section{Bole 12}

We now turn to languages of the "A" subgroup of West Chadic. As far as I know, there are no West Chadic " $A$ " languages that have anything resembling prosodic

12 This section is a write-up of an oral presentation given at the UCLA Linguistics Phonology Seminar, May 15, 2001. That presentation was, in turn, an expansion and refinement of a section of Schuh and Gimba [2000b]. Work on Bole has been supported by a National Science Foundation grant (BCS9905180, Russell G. Schuh, Principal Investigator). 
palatalization of whole words. Nonetheless, some West Chadic " $A$ " languages present problems of interpretation with respect to palatalization. In the preceding sections, I have tried to present a credible case for claiming that proto-West Chadic inherited morphological palatalization from its immediate ancestor. This background may give us a way to address some issues that West Chadic "A" languages raise.

The Bole phonetic coronal obstruent inventory includes the following sounds: [t, d, d, c, j, s, z, sh, nd, nj, nz]. There are no active alternations between any of the alveolars and their palatal counterparts, though a few frozen singular/plural alternants in nouns suggest that there was at one time at least a rule palatalizing $z$ before front vowels, e.g., gāzà, pl. gajje 'rooster', gorzo, pl. gorằji 'man'. In modern Bole, there are no such alternates associating the corresponding voiceless fricative pair $s / s h$, i.e., in a singular/plural pair like kòsum, pl. kosse 'rat', nor is there any evidence, internal or comparative, to suggest that the alveolar stops ever alternated with their palatal counterparts-cf. Bole dìshi-13 'grandchild' vs. Hausa $j \bar{i} k \bar{a}$, Bole $t i$ 'eat' vs. Hausa $c i$, where the Hausa cognates DO have palatals before front vowels. Discussion here will thus focus only on the sets $s / s h / c$ and $z / j$, assuming a historical relationship between the members of each set.

There is no question that $/ \mathrm{s}, \mathrm{sh} /$ and $/ \mathrm{z}, \mathrm{j} /$ represent four separate phonemes in Modern Bole. There are (near) minimal sets of words contrasting the alveolar and palatal counterpart of each pair (9). I include [c] in the palatal column together with [sh]. This sound occurs word initial in Bole in only a few words, always in variation with [sh]. Medially, [c] occurs only as a geminate in variation with [ssh].

(9) Bole words showing a contrast between alveolars and palatals

\begin{tabular}{|ll|ll|}
\hline \multicolumn{2}{|l|}{ Alveolar $(\mathrm{s}, \mathrm{z})$} & \multicolumn{2}{l|}{ Palatal $(\mathrm{sh} / \mathrm{c}, \mathrm{j})$} \\
\hline sit & ideophone for black & shit & ideophone for red \\
òsi & 'fire' & òshi & 'goat' \\
besì & 'shooting, stinging' & bè̀shi & 'pounding a nail' \\
sa & general negative marker & shầ & 'circumcision' \\
sap & ideophone for earliness & cap, shap & 'all' \\
dàsa & 'jealousy' & dàshà & type of sorghum \\
messè & 'remainder' & mècce & 'travelling' \\
\hline zà̀là & 'forked pole' & jàlà & Albizia chevalieri \\
zò̀ri & 'rope' & jol & ideophone for jumping \\
Gốzà & 'Goza person' & sốjà & 'soldier' \\
\hline
\end{tabular}

13 The plural dikkè 'grandchildren' shows the origin of the medial $s h<{ }^{*} \mathrm{k}$. This probably represents an innovation at the proto-Bole-Tangale level-cf. $2^{\text {nd }}$ feminine singular shi 'you' as the form for this pronoun in all the Bole-Tangale languages vs. Hausa $k i$. 
(10) Variation of palatals and alveolars within the Fika dialect

\begin{tabular}{|c|c|c|c|}
\hline $\mathrm{s} \sim \mathrm{sh} \sim \mathrm{c}$ & & $\mathrm{z} \sim \mathrm{j}$ & \\
\hline sònji shònji cònji & 'pumpkin' & zù̀lù jù̀lù & 'cooked pumpkin' \\
\hline sansala $\sim$ shanshala $\sim$ cancala & 'cattle egret' & zàutu jàutu & 'combing' \\
\hline insō $\sim$ inshō $\sim$ incō & 'today' & gòzor gòjor & 'throat' \\
\hline cap shap & 'all' & zâr jâr & 'a stick of ...' \\
\hline mànsuwò mànshuwò & 'he grew old' & zìrduwò̀yi jîrduwò̀yi & 'he tightened it' \\
\hline
\end{tabular}

(11) Variation of palatals and alveolars across dialects (some of these may also vary within a dialect)

\begin{tabular}{|c|c|c|c|c|c|}
\hline \multicolumn{3}{|l|}{$s \sim \operatorname{sh}$} & \multicolumn{3}{|l|}{$\mathrm{z} \sim \mathrm{j}$} \\
\hline Gadaka & Fika & & Gadaka & Fika & \\
\hline sìnsor & shìnshor & 'dew' & $z o$ & jo & 'running' \\
\hline sòmsòm & shòmshòm & 'fermented' & zànga & jànga & 'mud for building' \\
\hline dìsa & dìsha & 'vulture' & kanzàu & kanjàu & type of drum \\
\hline shèdi & sèdi & 'medicine' & wājà & wāzà & 'mare' \\
\hline
\end{tabular}

(12) Alveolar palatal variation affecting borrowed words

\begin{tabular}{|c|c|c|}
\hline Bole & Source & \\
\hline sàidu & shaidà $<$ Hausa $<$ Arabic & 'testify' \\
\hline shà̀shu sà̀su & sākè < Hausa & 'do again' \\
\hline zànkar (Gadaka) & $c f$. Ngizim jànkar̃ & 'louse' \\
\hline rìgìjâm rìgìzâm & rìgìzâm $<$ Kanuri < Arabic & 'bridle' \\
\hline
\end{tabular}


Despite the clear contrast between $/ \mathrm{z} /$ and $/ \mathrm{j} /$ and between $/ \mathrm{s} /$ and $/ \mathrm{sh} /$ (the latter with an allophone [c]), many words allow apparent free variation between alveolars and their palatal counterparts. This variation takes place both within the Fika dialect, the focus of this discussion, and across dialects (see (10)-(12)). Moreover, it affects borrowed words, sometimes depalatalizing an original palatal, sometimes palatalizing an original alveolar, and sometimes allowing variation.

The word meaning 'do again' from Hausa sākè (phonetically [sākyè̀]) is of particular interest. Bole speakers who have acquired Hausa in adulthood as a second language realize Hausa / ky/ and /gy/ as [c] and [j] respectively, e.g., Hausa dà kyâú 'good!' (lit: "with goodness") with a "Bole accent" becomes [dàcâu]. In Hausa, /k/ automatically palatalizes to / ky/ before front vowels, meaning that Bole speakers "hear" Hausa [sākyè̀] as [sācè̀], but because word medial [c] occurs only as a geminate realization of $/ \mathrm{sh} /$, this is reinterpreted as /sāshè/. As we will see below, alveolar and palatal fricatives cannot co-occur in the same word, meaning that the borrowed Hausa root must thus be either [sās-] or [shāsh-].

A number of questions arise from the observations that, on the one hand, the alveolar fricatives and their palatal counterparts are in contrast, whereas on the other hand, they seem to be in free variation in at least some words. The first question is the extent to which alveolar or palatal pronunciation is stable versus variable. Looking only at tokens from the Fika dialect, I compiled the following figures from Schuh and Gimba [2000a]:

Word initial

179 words with initial [s]

$\underline{82}$ words with initial [sh]

261 TOTAL with $\mathrm{s} \sim \mathrm{sh}$

13 show variation

Word medial (intervocalic C2)

109 words with [s] as $\mathrm{C} 2$

76 words with [sh] as $\mathrm{C} 2$ (includes [cc])

185 TOTAL with $\mathrm{s} \sim \mathrm{sh} \sim \mathrm{cc}$ as $\mathrm{C} 2$

6 show variation
114 words with initial [z]

$\underline{91}$ words with initial [j]

205 TOTAL with initial $\mathrm{z} \sim \mathrm{j}$

11 show variation
39 words with $[\mathrm{z}]$ as $\mathrm{C} 2$

$\underline{41}$ words with [j] as $\mathrm{C} 2$

80 TOTAL with $\mathrm{z} \sim \mathrm{j}$ as $\mathrm{C} 2$

6 show variation

These figures show that the number of words that admit alveolar/palatal variation is only a small percentage of the total of the words containing one of these sounds. The figures represent only those entries for which Schuh and Gimba [2000a] actually list variants. Were we to check every entry for acceptable variation, the figures would be considerably higher, but probably still well below $50 \%$. It is worth noting that no entries with medial geminates show variation within the Fika dialect, suggesting that gemination stabilizes an alveolar or a palatal pronunci- 
ation, though some entries with geminates differ dialectally, e.g., Fika pocco 'arrow', Gadaka posso.

Another question is whether there is any correlation between alveolar or palatal pronunciation and environment. The table in (13) gives figures for the four consonants in initial position before the five vowels of Bole. These figures include all tokens for each of the consonants. Thus, if a word has variants with both $s$ and $s h$, it is included with figures for both those consonants.

\begin{tabular}{|l|r|r|r|r|}
\cline { 2 - 5 } \multicolumn{1}{c|}{} & \multicolumn{1}{c|}{ s } & sh & \multicolumn{1}{c|}{$\mathrm{z}$} & \multicolumn{1}{c|}{$\mathrm{j}$} \\
\hline \#__i & 26 & 27 & 8 & 23 \\
\hline \#__e & 9 & 6 & 10 & 9 \\
\hline \#__a & 58 & 32 & 42 & 35 \\
\hline \#__u & 42 & 9 & 20 & 11 \\
\hline \#__o & $\underline{42}$ & $\underline{6}$ & $\underline{30}$ & $\underline{13}$ \\
\hline Total: & 177 & 80 & 110 & 91 \\
\hline
\end{tabular}

The only figure here that suggests that palatalization might be or have been in part phonologically conditioned is the fairly large difference in numbers of $z$ vs. $j$ before $i$. The palatals, especially $s h$, seem to be rather strongly DISfavored before the round vowels, but it is unlikely that this reflects a process of DEpalatalization, given the fact that /sh/ and /j/ are otherwise common sounds in Bole. In the case of $s / s h$ before $i$ and all the consonants before a, there is no obvious trend.

A final point of interest, alluded to in the discussion of Bole reflexes of the borrowed Hausa word sākè, is co-occurrence restrictions on alveolar fricatives and their palatal counterparts. In words that contain more than one such sound, all tokens of the sound must be either alveolar or palatal, as in (14). I found only two counterexamples to this generalization, viz. jè̀sa 'mane of a horse' and sōjà 'soldier' < Hausa < English.

shìnshor (Gadaka sìnsor) sōsò

jànja (Gadaka zànza)

zàzzoki

The facts regarding Bole alveolars vs. their palatal counterparts are reminiscent of the facts in languages with morphological palatalization: lexical contrasts can depend on the alveolar vs. palatal distinction; one finds alternants of the same root differing with respect to whether a coronal consonant is pronounced with alveolar or palatal articulation; alveolar tokens across the lexicon in general outnumber palatal tokens, and the number of words with alveolar vs. palatal variants is a relatively small percentage of the total words containing coronal consonants; 
palatal vs. non-palatal pronunciation tends to be a word level rather than a phoneme level difference.

With respect to this last observation, Bole has morpholexically related word pairs that could, in principle, be interpreted as involving word level prosody. Certain verb classes have verbal nouns and/or subjunctive forms ending in -e. When the verb root has an internal /-a-/, that vowel becomes [e], as in (15a). Similarly, in the demonstrative system, the proximal forms systematically have a vowel pattern -e...e- whereas the distal forms have a pattern -a...a-, as in (15b). Finally, there are a few etymologically related word pairs that are reminiscent of the types of pairing in Biu-Mandara and Miya, as in (15c).
(15)

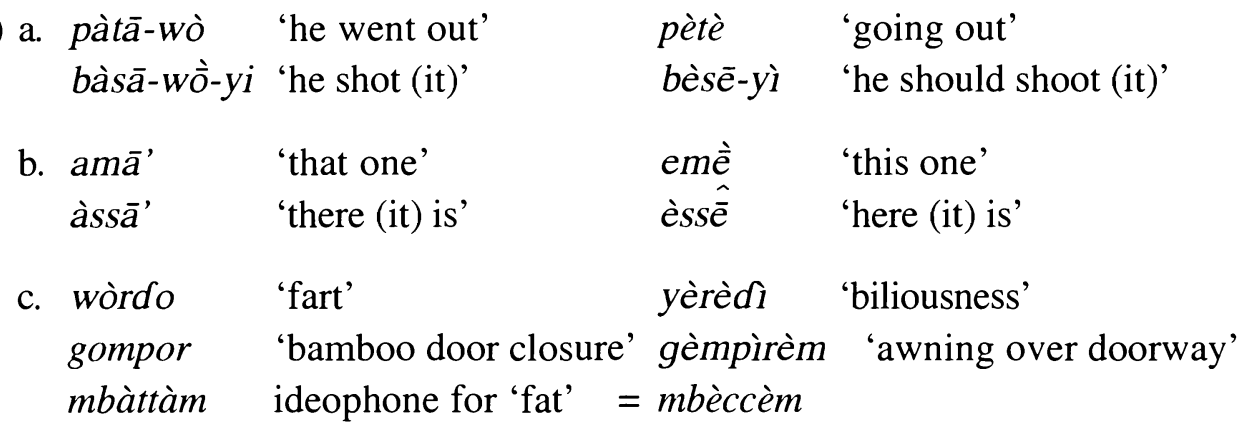

It is hard to say, however, whether this is best viewed as a word level prosody or as phonological assimilation. On the side of word level prosody associated with a particular morphological pattern is the fact that the an $a-e$ pattern is not phonologically disallowed, e.g., àrè 'type, race', màte 'them'. On the side of phonological assimilation, borrowed words with an a-e pattern in the donor language are usually adapted as e-e, e.g., rèke 'sugar cane' < Hausa ràkē, gède 'different' < Kanuri gàde 'other'.

There are some important differences between Bole and languages with morphological palatalization. First, in the latter type of language, words are either palatalized or they are not, whereas in Bole, while this is true for some words, other words vary in palatality. Second, a hallmark of morphological palatalization, even in languages like Miya or Duwai, where it is not productive, is that the presence or absence of palatalized consonants is associated with differences in morphology - perfective vs. other TAM's, finite verbs vs. verbal nouns, etc. In Bole, essentially the opposite is the case. Coronal consonants in a given root do not alternate regardless of vocalic context, i.e., the consonants of a root tend to retain a single phonetic identity in all their morphological instantiations. This is particularly clear in verbs, where nearly every verb root has forms ending in each of the five vowels of Bole. The table below shows just one root for each of the root final consonants /s, sh, $\mathrm{z}, \mathrm{j} /$, but this list of roots and the range of environments could be greatly expanded. The root final consonants of most verbs are stable, but the few 
verbs that have variable consonants can vary in all environments, e.g., busu-wò = bushu-wò 'he spent the day', bùsi = bùshi 'spending the day'.14

(16) Bole verb forms showing absence of consonant alternations with respect to following vowels

Non-front vowel environment

Front vowel environment

Invariable /s/

\begin{tabular}{|c|c|c|}
\hline bàsāwồyi & $\begin{array}{l}\text { 'he shot (it)' } \\
\text { 'he spun (it)' }\end{array}$ & $\begin{array}{l}\text { besì (*beshì) 'shooting' } \\
\text { bèse (*bèshe) }\end{array}$ \\
\hline
\end{tabular}

Invariable $/ \mathrm{sh} /$

\begin{tabular}{|ll|ll|}
\hline $\begin{array}{l}\text { pù̀shuwò̀yi } \\
\text { pù̀sha (*pùsa) }\end{array}$ & $\begin{array}{l}\text { 'he washed (it)' } \\
\text { 'washing' }\end{array}$ & pùshîi & 'wash (it)!' \\
\hline
\end{tabular}

Invariable /z/

\begin{tabular}{|ll|ll|}
\hline ùzāwò̀yi 'he spread (it) to dry' & ùzè (*ùjè) & 'spreading to dry' \\
\hline
\end{tabular}

Invariable / $\mathrm{j} /$ (the verb below is the only verb with a root final [j])

\begin{tabular}{|ll|ll|}
\hline $\begin{array}{l}\text { gòjjuwò̀yi } \\
\text { gojjo (*gozzo) }\end{array}$ & 'be bought (it)’ & gojjì & 'buying' (DVN) \\
\hline
\end{tabular}

In summary, Bole clearly does not have morphological palatalization as a productive or even moribund process. However, it shows a type of variation between alveolar consonants and their palatal counterparts that is not conditioned by local phonological environments nor is it a common type of variation crosslinguistically. In the historical context presented in the preceding sections, this rather unusual situation in Bole may find its source in an ancestral language where morphological palatalization created word variants that did not arise from local phonological conditioning. Association of variation in coronal consonants with specific morphological contexts was probably lost well before Bole became an independent language, but the variation itself persists.

\section{Hausa}

The status of palatalization in Hausa is reminiscent of that in Ngizim. Neither language exhibits the properties of morphological palatalization seen in BiuMandara languages or Miya. On the other hand, in both languages, there is a rule

14 The latter word is used in the common greeting, Barkà bùshi! 'Good afternoon!' I never heard this greeting pronounced as bùsi. This pronunciation may or may not be used, but if not, this is probably just a case where a specific pronunciation is stabilized in a particular context. 
changing alveolar stops and fricatives to their palatal counterparts before front vowels, and there are also lexical palatal consonants that have no apparent explanation in such a rule. Thus, in the same way that no rule of modern Ngizim can explain the relationship of the $j$ in $j a$ ' 'dog' to the $d$ in Bole àdà, no rule of Hausa can explain the relationship of $j$ in $j \bar{a}$ 'red' to the $d$ in Bole dài.

In the discussion below, I will first outline the facts of locally conditioned palatalization in Hausa. Next, I will note the existence of palatalized and palatal consonants in Hausa that the language must have inherited rather than developed through a locally conditioned palatalization process. This will provide prima facie evidence that many palatal consonants in Hausa have a source other than phonological assimilation, either synchronic or historical. I will then turn to the question of whether or not medial short [i] and [u] are in phonological contrast. In Modern Hausa, the source of differentiation of word pairs such as gidā 'house' vs. gùdā 'unit' or cinya⿳亠二 'thigh' vs. tunyầ 'cactus' is ambiguous between whether it is a contrast between the vowels, which condition differences in the consonants, or between the consonants, which condition differences in the vowels. I will argue that although the explanation for some palatal consonants in Hausa is undoubtedly palatalization of original alveolars before phonetically fronted high vowels, there is not now, nor has there probably ever been a phonological contrast between medial short [i] and [u] and that at least some palatal consonants before these vowels must have been inherited as palatals. One historical source of those inherited palatals may be morphological palatalization, which I have argued was a part of proto-West Chadic morphophonology.

\subsection{Palatalization of alveolars and consonants with palatal coarticulation.} Hausa has a well-documented rule that palatalizes alveolar modal obstruents before front vowels (see Newman [2000:414-417] for a fuller discussion). I illustrate this in (17) for all the relevant consonants before both front vowels.

This process is virtually $100 \%$ productive 15 for a range of morphological processes where a lexical base has variants with both final back and front vowels. Morphological forms where this arises include noun plurals, verbal nouns, and derived or inflected verbal forms, some of which are illustrated in the table in (17). There are also related forms that do not arise from productive processes but show palatalization, e.g., gazàa 'lack' vs. gàji 'be tired', sanì = shinà̀ 'know', zama 'remain, stay' vs. jimà 'spend time'. Note that in the latter two cases, palatalization takes place before an internal vowel.

Despite the productivity of alveolar alveopalatal alternation, Newman [2000: 414 ] points out that palatalization does not have the status of a productive phonological rule in modern Hausa. Alveolar consonants before front vowels in loan-

15 Newman [2000:415-416] notes that /d/ has a different status from the other consonants. First, /d/ systematically fails to palatalize if preceded by $n$, e.g., gìnd 'base' (cf. hancì 'nose', pl. hantunà). Second, there are numerous words in which /d/ does not palatalize in environments where the other consonants would, e.g., bidà 'thatching needle', pl. bidōdì (cf. the singular and plural of 'flag' in the table). 
(17) Palatalization of Hausa alveolar obstruents before front vowels

\begin{tabular}{|c|c|c|c|c|}
\hline \multicolumn{5}{|c|}{$I \ldots$} \\
\hline$t \rightarrow c$ & tūtà̀ & 'flag' & tūtōcì & 'flags' \\
\hline $\mathrm{d} \rightarrow \mathrm{j}$ & $g \bar{a} d \bar{े}$ & 'inheritance' & gã̃ājijiyā & 'tradition' \\
\hline $\mathrm{s} \rightarrow \mathrm{sh}$ & gasà & 'roast' & gashì & 'roasted meat' \\
\hline $\mathrm{z} \rightarrow \mathrm{j}$ & kà̀zā & 'hen' & $k \grave{\bar{a}} \bar{j}$ & 'chickens' \\
\hline
\end{tabular}

\begin{tabular}{|llll|}
\hline sātà̀ & 'theft' & sācè̀ & \\
\hline gudù & 'run' & à gù̀je & 'at a run' \\
\hline dasà̀ & 'transplant' & dàshē & 'seedlings' \\
\hline bazà̀ & 'spread' & bajè̀ & 'scatter' \\
\hline
\end{tabular}

(18) Contrast between plain, labialized, and palatalized velars

\begin{tabular}{|l|l|l|ll|}
\hline Plain & Labialized & Palatalized & \\
\hline kanwā 'potash' & kwanyā 'occiput' & kyanwà & 'cat' \\
\hline gārā 'wedding gifts' & gwāri 'grasshopper sp.' & gyārā & 'repair' \\
\hline Kaurī 'smell of burning hair' & Kwàurī 'shin' & Kyaurē & 'door panel' \\
\hline
\end{tabular}


words do not undergo palatalization, even though they are subject to other phonological adaptations such as epenthesis and epheresis, e.g., tikiti 'ticket', tilàs 'necessarily' (< Fulfulde), digìnî '(university) degree', sìyāsầ 'politics' (< Arabic), zìna 'fornication' (< Arabic). Alveolars in loanwords do generally palatalize when they participate in one of the regular processes that condition palatalization in native words, e.g., tikitōci 'tickets', with $t \rightarrow c$ in the reduplicated plural. In addition to borrowed words, there are some apparent native words, especially with initial $t$, that have not undergone palatalization, e.g. tik $\bar{a}$ 'make a huge thing, such as a granary'. The facts as we have them in modern Hausa therefore do not present unequivocal evidence that palatalization of alveolars before front vowels was ever an automatic phonological rule.

Modern Hausa has a three-way contrast in velar consonants between plain velars, velars with labial co-articulation, and velars with palatal co-articulation, as shown in (18).

Plain velars and velars with labial co-articulation appear universally in Chadic languages and obviously formed part of the proto-Chadic phonological system. Velars with palatal co-articulation, on the other hand, are much less common. Indeed, other than Hausa, the only languages I know of that have palatalized velars in contrast with plain and labialized velars are languages with morphological palatalization or clear remnants of it. Some dialects of Hausa also have a small number of words with palatalized labials in contrast with plain labials, though Standard Hausa has tended to lose the palatalization in such words. (No dialect of Hausa has palatalized $m y$.)

(19) Hausa dialectal forms with palatalized labials

\begin{tabular}{|c|c|c|c|}
\hline \multicolumn{2}{|l|}{ Plain } & \multicolumn{2}{|l|}{ Palatalized } \\
\hline bàllē & 'how much less...' & byallo $=$ ballō & 'a spark' \\
\hline bātà & 'spoil' & byà̀sā = 6à̀sā & 'twist or pluck off fruit' \\
\hline$f \bar{a} d \bar{a}$ & 'fall on' & fyādà̀ = fādà̀ & 'hit with flexible whip' \\
\hline fầcē & 'except that' & fyāc ̀̀ $=$ fācè & 'blow one's nose' \\
\hline
\end{tabular}

I see no explanation for the existence of palatalized velars and labials in apparently native Hausa words other than inheritance. The fact that palatal coarticulation as a phonological feature in Chadic languages seems to be almost entirely restricted to languages that have morphological palatalization suggests that Hausa has inherited these consonants from an ancestral language that had this property.

5.2. Inherited (alveo)palatal consonants. Hausa does not have any coronal consonants with palatal co-articulation. The palatalized counterparts of alveolar obstruents $(t y, d y$, etc.), if they ever existed, have fallen together with the alveopalatal coronals $(c, j$, etc.). Palatalized sonorants $(r y, n y$, etc.), if they ever existed, have fallen together with their plain counterparts. Although Hausa does have a 
conditioned rule palatalizing coronal obstruents, it must also have inherited words with palatal coronals in contrast with alveolars. This is most obvious in words where /a/ or /ā/ follow the palatal, e.g., shā 'drink', jā 'red', caf'è 'catch'. In such words, the existence of a palatal has no phonological explanation. To get a rough idea of how alveolars and their palatal counterparts are distributed with respect to following vowels, I counted the number of pages in Bargery [1934] of words beginning in CorV, where Cor = each of the coronal (= alveolar and palatal $)$ obstruent consonants and $V=$ each of the five vowels. In the tables in (20), the numbers under the consonant represent the number of pages in Bargery for each CorV combination. The numbers for $d$ are inflated because Bargery mixes modal $d$ and implosive $d$.

(20) Number of pages in Bargery [1934] for \#[+coronal] V...

Voiceless

\begin{tabular}{|c|c|c|c|c|c|c|c|c|}
\hline Cor & $\mathbf{t}$ & $\%$ of $\mathbf{t}$ & c & $\%$ of $\mathrm{c}$ & $\mathbf{s}$ & $\%$ of $\mathrm{s}$ & sh & $\%$ of $\mathrm{sh}$ \\
\hline $\mathrm{a}$ & 48.00 & $64.00 \%$ & 8.00 & $29.09 \%$ & 45.00 & $69.23 \%$ & 17.00 & $59.65 \%$ \\
\hline $\mathrm{i}$ & 4.50 & $6.00 \%$ & 12.00 & $43.64 \%$ & 4.00 & $6.15 \%$ & 7.00 & $24.56 \%$ \\
\hline $\mathrm{u}$ & 19.00 & $25.33 \%$ & 3.00 & $10.91 \%$ & 13.00 & $20.00 \%$ & 2.00 & $7.02 \%$ \\
\hline $\mathrm{e}$ & 0.50 & $0.67 \%$ & 1.50 & $5.45 \%$ & 0.00 & $0.00 \%$ & 2.50 & $8.77 \%$ \\
\hline o & 3.00 & $4.00 \%$ & 3.00 & $10.91 \%$ & 3.00 & $4.62 \%$ & 0.00 & $0.00 \%$ \\
\hline Total & 75.00 & & 27.50 & & 65.00 & & 28.50 & \\
\hline
\end{tabular}

Voiced

\begin{tabular}{|c|c|c|c|c|c|c|}
\hline Cor & d & $\%$ of $d$ & $\mathbf{z}$ & $\%$ of $\mathrm{z}$ & $\mathbf{j}$ & $\%$ of $\mathbf{j}$ \\
\hline $\mathrm{a}$ & 76.00 & $67.56 \%$ & 22.00 & $30.56 \%$ & 11.50 & $40.35 \%$ \\
\hline $\mathrm{i}$ & 11.50 & $10.22 \%$ & 21.00 & $29.17 \%$ & 12.00 & $42.11 \%$ \\
\hline $\mathrm{u}$ & 17.00 & $15.11 \%$ & 9.00 & $12.50 \%$ & 2.00 & $7.02 \%$ \\
\hline $\mathrm{e}$ & 1.00 & $0.89 \%$ & 0.00 & $0.00 \%$ & 2.50 & $8.77 \%$ \\
\hline $\mathrm{o}$ & 7.00 & $6.22 \%$ & 20.00 & $27.78 \%$ & 0.50 & $1.75 \%$ \\
\hline Total & 112.50 & & 72.00 & & 28.50 & \\
\hline
\end{tabular}

Of particular interest is the comparison of the numbers for $\mathrm{Ca}$ vs. $\mathrm{Ci}$. If local palatalization of alveolars were a major factor in accounting for words with initial palatal consonants, then we would expect a strong skewing of alveolars toward a following $a$ and palatals toward a following $i$. The alveolar sounds $t, s$, and $d$ do show much higher figures in / a than in $/$ $i$, but the palatal counterparts $c, s h$, $j$ show nothing like a complementary skewing. Indeed, the distribution of $s h$ is skewed IN FAVOR OF the $/ \ldots$ a environment at a level comparable to the alveolars. And though $c$ is somewhat skewed toward / $i$ as compared to $/$ $a$, the total percentage of $c$ before the back vowels $u$ and $o(21.82 \%)$ is comparable to that for its alveolar counterpart $t(29.33 \%)$. In short, though these counts provide a rather 
gross way of estimating CorV distribution, it is obvious that there are far too many words with unconditioned palatals in Hausa to warrant any source other than direct inheritance. The two possible (though not mutually exclusive) sources are the presence of palatals in the original phoneme inventory and the effect of morphologically conditioned palatalization on underlying alveolars.

\subsection{Hausa high vowels and the source of phonologically conditioned word} initial palatals. Section 5.1 presented an active rule that palatalizes underlying alveolar consonants before front vowels, but this rule is confined almost entirely to word final morphological alternations. In particular, it does not apply to word initial C $i$ sequences, e.g., tikitì 'ticket', not * cikitì or * cikicì. Section 5.2 provided data on the distribution of alveolar and palatal consonants. This data showed that Hausa must have inherited word initial palatal consonants. The distributional patterns show that Hausa has significant numbers of palatals that cannot trace their origin to phonologically conditioned palatalization of erstwhile alveolars.

There is, however, a modern Hausa relationship between coronal consonant types and vowel types: words like cika 'be full', with an initial palatal, are pronounced with an invariable [i], whereas words like tùkä/tìkā 'ruminating', with an initial alveolar, tend to be pronounced with $[\mathrm{u}]$ or to vary dialectally or even idiolectally between [u] and [i]. A not-unreasonable hypothesis would be that pairs like this represent an original distinction between $*_{t i}$ and $*_{t u}$, that a once fully active palatalization rule changed the former to $c i$, and that only later did the palatalization rule become restricted as it is now. Put differently, pairs of words like those just cited could provide evidence for a proto-Hausa distinction between medial short $*_{i}$ and $*_{u}$. In the remainder of this paper, I will argue that this is incorrect. Hausa does not now have nor has it ever had a phonemic distinction between medial short /i/ and /u/. The implication of this claim is that NO initial palatals can trace their origin to palatalization of alveolars before an underlying medial /i/. Many, if not most words with initial palatals, such as cika, probably have been inherited as such, and it is the consonant that conditions the invariable front vowel. Vowel variation after alveolars, as in tùk $\bar{a} / t \grave{i} K \bar{a}$, reflects the non-contrastive nature of the phonetic vowels. Some word initial palatals may derive from erstwhile alveolars through phonological processes, but a path for this exists without reconstructing a medial contrast between short /i/ and /u/.

5.3.1. The Hausa vowel system. Hausa has a 10 way vowel contrast in word final position, i.e., the five vowels $i, e, a, u, o$ both long and short, and a five way contrast word medial between the five long vowels (see (21)). There is no contrast between short medial $a, e$, and $o$. Medial short mid vowels are neutralized to short [a]. For example, when the "definite article" : $n$ is added to the words karā 'stalks', kàrē 'dog', and karò 'collision', closing the final syllables and automatically shortening the final vowels, the words in normal speech are distinguished only by tone, viz. [karây], [kàrây], [karày], respectively.

On these facts, all Hausa language specialists agree as far as I know. The main problems of analysis in Hausa vowel phonology are in the analysis of medial short 
(21) Final and medial Hausa vowel contrasts

\begin{tabular}{|c|c|c|c|}
\hline \multicolumn{2}{|l|}{ Final } & \multicolumn{2}{|l|}{ Medial } \\
\hline tārì̀ & 'a collection, a pile' & rìmì & 'kapok tree' \\
\hline fārì & 'beginning' & & \\
\hline (tā) $t a \bar{r} \check{\bar{e}}$ & '(she) moved to new house' & rēmā & 'hyrax' \\
\hline tà̀re & 'together' & & \\
\hline (ȳ̄) tārà̀ & '(he) collected' & rāmì̀ & 'hole' \\
\hline tar̃à & 'nine' & & \\
\hline tārū & 'fishing net' & rū6è & ‘spoil’ \\
\hline (sun) tà̀ru & '(they) gathered' & & \\
\hline tà̀rō & 'gathering' & rōmō & 'broth' \\
\hline Màiîro & a woman's name & & \\
\hline
\end{tabular}

high vowels. One position, taken most forcefully by Paul Newman [see Newman 1979:175-176, Newman 2000:400, 414], maintains that medial short /i/ and /u/ are in contrast, or at least have been until recently. The other position-the one taken in this paper-is that these vowels are not in contrast, or, put another way, in nonfinal position, the only contrastive feature between short vowels is [+high] vs. [-high]. 16

The traditional method for demonstrating a contrast between segments is to cite minimal pairs. Though this type of argument has been used to support a contrast between medial short high vowels, the evidence is equivocal at best. Some pairs, like cika/tùka, cited in the previous section, are not "minimal", in that both the vowels and the consonants differ. Thus, depending on one's point of view, these pairs could support either a position that vowels influence consonants or consonants influence vowels. There are putative pairs like riga 'precede' vs. rugā 'Fulani camp', where appeal to consonantal effect is absent, but such examples are hard to come by, and I have seen no such pairs where questions about the validity of the data do not arise. For example, during a recent trip to Nigeria, I heard the word for 'Fulani camp' pronounced [rigā] on two different occasions by different speakers in different towns. The dictionaries give rugā for 'Fulani camp', but we have no knowledge of the source of this word in terms of speaker, place, or time, much less whether the speaker(s) who provided this word contrasted it with [rigā] 'precede'.

16 As in many other areas of Hausa grammar, F.W. Parsons was the pioneer in the analysis of Hausa vowels, and in particular, in the proposal that medial short [i] and [u] are not in contrast. He first laid out his analysis in a massive manuscript, Parsons [n.d.], major ideas of which were published in more succinct form in Parsons [1970]. Parsons' analysis, influenced by the ideas of J. R. Firth, accounted for phonetic realization of words in terms of "prosodies" over domains greater than individual segments. One need not accept Parsons' analytical framework in order to accept his insight that the coloring of medial short high vowels is directly linked to the consonantal environment. 
There is one type of apparently true minimal pair where the data are not in dispute. These are pairs of words containing the sequence VELAR $+i \sim u$., e.g. gidā 'house' and gùdā 'lump, unit'. But the standard orthography is deceptive. These words are pronounced [gyidā] and [ $\left.g^{\mathrm{w}} \mathrm{u} d \overline{]}\right]$, respectively. Front vowels condition palatalization of preceding velars and round vowels condition labialization, so one could argue that the vowels contrast and condition the differences in the velars. However, as demonstrated in $\$ 5.1$, Hausa has an independently required contrast between plain, palatalized, and labialized velars. One can thus argue that it is the velars which contrast here and that they condition fronting or backing and rounding of the following vowel, a process that unambiguously accounts for vowel quality differences in languages like Miya and Ngizim. In Ngizim, kə̀ru 'steal' differs minimally from kùru 'refuse'. Like Hausa, Ngizim has a contrast between /i/ and /u/ before pause, e.g. gazabì 'kite' vs. gàbābù 'billygoat', but phrase medial, this contrast is neutralized to $[\varnothing, ə, \mathrm{i}, \mathrm{u}]$ depending on the environment, e.g., gazab̀̀ bai 'not a kite', gàbābà bai 'not a billygoat'. The contrast between k̇̀ru and kùru therefore cannot reside in the vowels. It must be a function of the initial consonants, viz. /kə̀ru/ vs. /kwòru/. The only difference between Ngizim and Hausa would thus be the phonetic range that the languages allow for their high vowels.

Newman has another type of argument, first laid out in Newman [1979:175176], for at least a historical contrast between medial /i/ and / $\mathrm{u} /$. In such words as cinyà̀ 'thigh' vs. tunyà̀ = tinyà̀ 'cactus', he argues that if there were not a contrast between a front and a back high vowel, there would be no explanation for why one word begins with a palatal and the other with an alveolar. He explains non-palatalization of initial $t$ - in the variant tinyaे 'cactus', with [i] in the first syllable, by "the ongoing shift of short / $\mathrm{u} /$ to / $\mathrm{i} /$ in various environments" [Newman 2000:414]. My explanation for the pronunciation of the vowels in these words is that the invariant [i] in cinyaे is a result of the strong fronting influence of the preceding palatal, whereas the variation in tunyàे vs. tinyà comes about

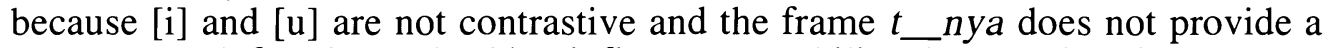
strong enough fronting or backing influence to stabilize the vowel. This response, of course, begs the question as to where the palatal of cinyà came from in the first place. My answer, as already suggested, is that it probably has been inherited from ${ }^{*}$ c. Alternatively, it may be the result of phonological palatalization of $* t$, but even if this is the source, we are not forced to accept a phonemic contrast between medial /i/ vs. /u/.17

There are two facts about medial short high vowels that all Hausa specialists would accept: (1) short high vowels are subject to dialectal and local environmentally conditioned variation, and (2) the short high vowels tend to gravitate

17 The cinyà)/tunyà case may have another explanation. Bargery gives a dialect variant tumniyã for 'cactus', suggesting that an original $-m$ - in this word exercised a labializing influence that prevented palatalization of the initial consonant (see below). The facts about these particular words do not, however, invalidate the general principle of Newman's observation about words differing in $c i$ - vs. $t u$-/ti- and parallel pairings of other palatals vs. alveolars. 
phonetically to either high front unrounded or high back rounded vowel space. 18 On the one hand, these facts about Hausa account for variants such as bùkī vs. bìkì 'celebration' or jimà̀ vs. jumà 'spend time', and on the other hand, they allow Hausa orthography to get by with just five vowel symbols. ${ }^{19}$ The factors influencing vowel quality are complex, but they include at least the following:

- Consonants preceding and following the vowels (note that the illustrative words in the preceding paragraph have an internal conflict between labializing and palatalizing influences, accounting for the variation).

- Vowels in preceding and following syllables (the word tudù 'hill', with final $-u$ has no variant *tidù, but tinà/tunà̀ 'remember', with final -a has $i / u$ variation).

- Lexical or other "external" knowledge: Newman [2000:319-321] notes how loanwords have introduced distinctions not part of the original phonology of Hausa, e.g., toleration of short mid vowels in closed syllables in words such as bencì 'bench'. Speakers who pronounce the word this way undoubtedly do so because they know the English source. Similar knowledge probably has a dampening effect on expected neutralization or variation. For example, the word dòmin 'because' has a shortened variant don, typically pronounced with a round mid vowel even though shortened mid vowels usually neutralize to [a]; the plural of tudì 'hill' is tùddai, a frame that should normally admit variation with *tìddai, though this pronunciation is probably never used because of the invariant pronunciation of the singular with $-u$-.

5.3.2. Conditioning factors of medial short high vowels and effects on coronal consonants. This section argues as follows: medial short high vowels are not in contrast-phonetic distinctions in short high vowels result from environment, particularly immediately neighboring consonants, but also segments in neighboring syllables. Nonetheless, vowels can also affect consonants. In particular, if the environment following a vowel is conducive to an " $i$-like" pronunciation of the vowel, the vowel itself may then have an effect on the consonant that precedes it. If the preceding consonant is an alveolar, that affect could be full palatalization. I will adduce distributional evidence drawn from entries in Bargery [1934] to show that there is a moderate skewing toward palatal consonants where the consonant subsequent to the palatal is conducive to an [i] rather than $[\mathrm{u}]$ pronunciation of the preceding vowel. Were $/ \mathrm{i} /$ and $/ \mathrm{u} /$ contrastive segments, with palatalization of an

18 In this latter respect, Hausa differs from some of its Chadic cousins, like Ngizim or Miya, which tend to use the entire high vowel space and in which the most "neutral" high vowel pronunciation is a central unrounded [i], written " $\partial$ " in the Chadic literature.

19 Though five written vowels serve quite well in a practical orthography, the exact vowel quality of short high vowels in some environments is often indistinct, serving more as a vocalic transition between consonants than as a clear front or back vowel. On more that one occasion, I have seen Hausa speakers hesitate as to which vowel to write, and one finds considerable spelling variation in modern published works. 
alveolar taking place before /i/, we would predict no correlation at all between palatal segments and subsequent consonants. Though I suspect that Hausa inherited most initial palatal segments as palatals, it may thus be the case that at least some palatals are a result of palatalization of alveolars induced by [i] vowels that themselves were the result of environmental conditioning.

Let us work from the following premises:

Premise 1: The vowels [i] and [u] are not in phonological contrast but owe their phonetic realization to the factors listed at the end of the preceding section.

Premise 2: There is a tendency to palatalize alveolar consonants before front vowels.

If these premises are valid we can make two corollary predictions:

Corollary 1: The pronunciation of high vowels will be less variable in strongly fronting or backing environments than in more "neutral" environments.

Corollary 2: There will be more of a tendency to find palatal consonants before vowels in fronting environments than backing environments.

To test these predictions and their corollaries, I made lists of all the words in Bargery [1934] with the consonants $t, s, c$, and $s h$ in word initial position before short $i$ and $u .20$ I excluded borrowed words and phonaesthetic words such as ideophones, which are less subject to the phonological canon than other categories, and I listed words containing the same root in only one form, e.g., I listed cika 'be full' but not cikà 'fill', cikò 'completion', cìke 'filled', cikàsā 'complete', etc. Bargery is particularly useful for a study like this because he includes all the phonological variants (dialectal or individual) that he recorded as well as many dialectally restricted words. The figures I assembled must be viewed as approximationsborrowings undoubtedly slipped in, there are probably some repeated listings of the same root (are silla 'eat large quantity of good tuwo', sillā 'stalk used as spinning stick', sillè 'get free', sille 'wear gown without trousers' somehow related?), and there are surely many cases where Bargery did not list existing variants simply because they did not come to his attention. Nonetheless, the samples are large enough that a fairly compelling picture emerges.

To keep the number of variables under control, I restricted my listings to two environments: those where the CV- of interest was immediately followed by a labial consonant or a labialized velar (abbreviated "P" and "Kw" below) and

20 I did not make similar counts for the voiced coronals. This was partly because of the tedium of assembling such lists, but the resulting picture would also probably not be as sharp as for the voiceless sounds. As noted above (see fn. 15), $d$ has been less subject to palatalizing influence than the other alveolars, and moreover, palatalized $d$ and $z$ have fallen together as $j$, making it impossible to compare the numbers of words with $d$ and $z$ with the numbers of words having their palatalized counterparts. 
those where the CV-was immediately followed by a coronal or a non-labialized velar (abbreviated "T" and " $\mathrm{K}$ " below). In the case of consonant sequences in the following environment, I listed $\mathrm{NC}(\mathrm{N}=$ nasal homorganic to $\mathrm{C}$ ) with words having singletons at the same point of articulation. Syllable final liquids and $s / z$ turn out to be "transparent" in terms of conditioning effect, so I included words like turmī 'mortar', sulbi 'slipperiness', tusmà "the evil eye" in the lists with the "P" environment. The table in (22) gives small representative sets of the types of words in the lists. I show variants separated by a slash where Bargery lists them. Bargery shows no variants for the other words. I have taken a few liberties with glosses to make them fit on one line.

Consider first the distribution of the vowels [i] vs. [u] by environment:

- $t \mathrm{~V}, s \mathrm{~V} / \ldots \mathrm{T} / \mathrm{K}$ : Bargery gives variants with $\mathrm{V}=i$ and $u$ for $10-20 \%$ of these. For the remainder he gives roughly half with $i$, half with $u$. Bargery could, of course, give variants only where he actually attested them. I have personally never heard many of the words in these lists, but for at least some of those that I do know, I have heard variants that Bargery does not list. For example, he gives only surkaे 'mix a liquid or grain into water', but the pronunciation I first heard for this word was sirkà (which I included in the table above). My guess is that ALL these words admit variation, though the following syllable may sometimes also exercise an influence.

- $t \mathrm{~V}, s \mathrm{~V} /$ P/Kw: Out of a list of 50 words for $s \mathrm{~V}$, Bargery has only 3 with $i$, two of which have variants with $u$. Out of a list of 98 words for $t \mathrm{~V}$, Bargery gives only two with $i$, one of which has a variant with $u$. The only explanation for this distribution is that the labiality of the following consonant is determining the pronunciation of the vowel.

- $c \mathrm{~V}, \operatorname{sh} \mathrm{V} / \ldots \mathrm{T} / \mathrm{K}$ : The only vowel in these environments is $i$, i.e. vowel pronunciation correlates directly with preceding consonant.

- $c \mathrm{~V}, \operatorname{sh} \mathrm{V} / \ldots \mathrm{P} / \mathrm{Kw}$ : The only vowel in $/ \_\mathrm{P}$ is $i$. In $/ \_\mathrm{Kw}$, the vowel $u$ strongly predominates. There are only four words with $s h \mathrm{VKw}$, in all of which $\mathrm{Kw}=w .21$ Bargery gives two of these with $i$ (cf. shirwà in the table above). Out of 17 words with $c \mathrm{VKw} .$. , Bargery has only 6 where $\mathrm{V}=i$, one with a variant $u$ (cukwīkwiyā = cikwīkwìyā 'become tangled').

With a "neutral" consonant ( $t, s$ in this case) preceding and a "neutral" environment following ( $\mathrm{T} / \mathrm{K}$ in this case), the vowels [i] and [u] are subject to dialectal or idiolectal variation. With a "neutral" consonant $(t, s$ in this case) preceding and a labializing environment following (_ $\mathrm{P} / \mathrm{Kw}$ in this case), the only vowel is $[\mathrm{u}]$. To claim that the high vowels are now, or at some time in the nottoo-distant past have been in contrast would predict relative stability of specific vowels across dialects and a fairly free and unpredictable distribution of the two vowels regardless of environment. The distribution documented here shows that neither of these predictions is borne out.

21 I concur with Newman's [2000:392,416] phonological classification of $w$ with the labialized velars. 
(22) Sample words with \#[+coronal $] i / u$ intial syllables

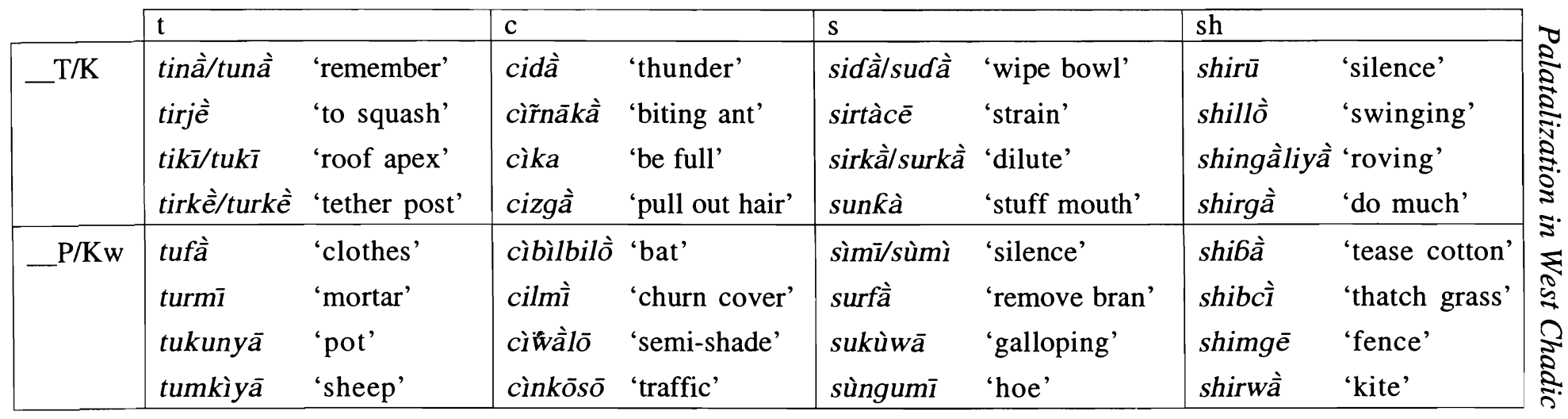


In support of a vowel contrast, one could argue that ALL these cases where the preceding consonant is an alveolar are reconstructable as $* \mathrm{Cu}$-. Original ${ }^{*} \mathrm{Ci}$ - is represented by the words beginning with palatals, where $i$ is the exclusive vowel except for words with the strongest labializing environment, /__ $\mathrm{Kw}$, following. In order to avoid circular reasoning in favor of either the "no vowel contrast" hypothesis or the " $/ \mathrm{i} / \sim / \mathrm{u} /$ contrast" hypothesis, we need additional evidence. Such evidence can be found in the distribution of syllables following the syllable beginning with a palatal, i.e., whether or not the following environment would be conducive to conditioning a vowel that itself might cause palatalization of an alveolar. The predictions are as follows:

- The "contrast" hypothesis ( $i$ and $u$ are in phonological contrast) predicts that the distribution of initial $\Pi i$ - syllables ( $\Pi=$ palatal consonant $)$ across the lexicon should be unrelated to anything about the phonological form of the rest of the word.

- The "no contrast" hypothesis ( $i$ and $u$ are conditioned variants of a single vowel phoneme) predicts that $\Pi i$ - syllables should be favored where the following environment is conducive to conditioning a preceding [i] and should be disfavored where the following environment is conducive to conditioning a preceding $[\mathrm{u}]$.

Data above suggested that the environment /_ T/K, while not strongly conditioning preceding [i], is compatible with it. Data for the environment /_ P/Kw, on the other hand, essentially precludes [i] except where the preceding consonant is a palatal. For simplicity, we will thus call /_ T/K a "fronting" environment and I_ P/Kw a "backing" environment. Consider the figures in (23) based on the lists assembled from Bargery.

Syllables beginning with the alveolar segments $t$ and $s$ though not strongly skewed toward either environment, slightly favor the "backing" environment: $53.9 \%$ and $54.3 \%$, respectively, in /_P/Kw vs. $46.1 \%$ and $45.7 \%$, respectively, in I_T/K. Syllables beginning with the palatal segments $c$ and $s h$, on the other hand, appear nearly twice as often in "fronting" environments as in "backing" ones: $39.2 \%$ and $33.9 \%$, respectively, in /_P $/ \mathrm{Kw}$ vs. $60.8 \%$ and $66.1 \%$, respectively, in I_ T/K. These figures support the "no vowel contrast" hypothesis, i.e., if palatalization of alveolars were a result solely of the presence of a following underlying $/ \mathrm{i} /$, there would be no reason to expect any correlation at all with the environment following the syllable with the palatal, much less a correlation one way with syllables beginning in alveolars as a group vs. a correlation the other way with syllables beginning in palatals as a group. Note furthermore that in terms of absolute numbers, there are over twice as many syllables beginning in alveolars as in palatals, a distribution that is similar to that of languages with morphological palatalization, but not one that would be predicted under the "vowel contrast" hypothesis assuming that there would be about as many words containing internal $/ \mathrm{i} /$ as internal $/ \mathrm{u} / .22$ 
(23) Distribution of [+coronal] V syllables with respect to the following consonantal environment

\begin{tabular}{|c|c|c|c|c|c|c|c|}
\hline $\mathrm{t} / \mathrm{P}$ & $\mathrm{t} / \mathrm{Kw}$ & $\mathrm{t} / \mathrm{T} / \mathrm{K}$ & Total $t$ & $\mathrm{c} / \ldots \mathrm{P}$ & $\mathrm{c} / \mathrm{Kw}$ & $\mathrm{c} / \mathrm{T} / \mathrm{K}$ & Total $c$ \\
\hline $\begin{array}{l}60 \\
33 \% \\
\end{array}$ & $\begin{array}{l}38 \\
20.9 \% \\
\end{array}$ & 84 & 182 & $\begin{array}{l}12 \\
16.2 \%\end{array}$ & $\begin{array}{l}17 \\
23 \% \\
\end{array}$ & 45 & 74 \\
\hline \multicolumn{2}{|c|}{$53.9 \%$} & $46.1 \%$ & & \multicolumn{2}{|c|}{$39.2 \%$} & $60.8 \%$ & \\
\hline \multicolumn{3}{|c|}{$\%$ of all $\mathrm{t}, \mathrm{c}$} & & \multicolumn{3}{|c|}{$\%$ of all $\mathrm{t}, \mathrm{c}$} & Total t,c \\
\hline \multicolumn{2}{|c|}{$38.3 \%$} & $32.8 \%$ & & \multicolumn{2}{|c|}{$11.3 \%$} & $17.6 \%$ & 256 \\
\hline
\end{tabular}

\begin{tabular}{|c|c|c|c|c|c|c|c|}
\hline $\mathrm{s} / \mathrm{P}$ & $\mathrm{s} / \ldots \mathrm{Kw}$ & $\mathrm{s} / \mathrm{T} / \mathrm{K}$ & Total $s$ & $\operatorname{sh} / \ldots P$ & $\mathrm{sh} / \mathrm{Kw}$ & $\mathrm{sh} / \mathrm{T} / \mathrm{K}$ & Total sh \\
\hline $\begin{array}{l}22 \\
23.9 \% \\
\end{array}$ & $\begin{array}{l}28 \\
30.4 \% \\
\end{array}$ & 42 & 92 & $\begin{array}{l}15 \\
26.8 \% \\
\end{array}$ & $\begin{array}{l}4 \\
7.1 \% \\
\end{array}$ & 37 & 56 \\
\hline \multicolumn{2}{|c|}{$54.3 \%$} & $45.7 \%$ & & \multicolumn{2}{|c|}{$33.9 \%$} & $66.1 \%$ & \\
\hline \multicolumn{3}{|c|}{$\%$ of all s, sh } & & \multicolumn{3}{|c|}{$\%$ of all s, sh } & Total s,sh \\
\hline \multicolumn{2}{|c|}{$33.8 \%$} & $28.4 \%$ & & \multicolumn{2}{|c|}{$12.8 \%$} & $25 \%$ & 148 \\
\hline
\end{tabular}


One figure among the palatals in (23) stands out, viz. sh in /_P. This configuration represents over a quarter of all the cases of $s h \mathrm{~V}$ syllables. Nine of the 15 tokens of this configuration have closed initial syllables, e.g., shibcì 'thatch grass' ( $>$ shūcì in Kano Hausa), shibkà 'plant' ( $>$ shūkà̀ in Kano Hausa), shimgē 'fence' (> shingē in Kano Hausa), shìrbàcē 'confusion'. Indeed, there are no words in any dialect of modern Hausa with the form si/uPC... (P = any labial consonant, $\mathrm{C}=$ any non-labial), a fact that Paul Newman pointed out to me in personal communication. Using $\partial$ as a cover symbol for any short high vowel, it appears that the historical development $*_{\partial}>[i] / s \ldots[$ +grave $] C \ldots$ and $*_{s}>s h$ $I$ [i] has the status of regular sound change in the Neogrammarian sense, explaining why all cases of Klingenheben's Law involving syllables of the form * səK/PC have $s h$ in modern Hausa, including not only the examples cited above with syllable final labials, but also syllables reconstructed as having been closed by velars as in shūnà 'incite' <*shikna (cf. dialect variant kiznà, probably also related to sàkā 'release'), shūdà 'mentally deficient person' < *shikda (cf. doublet sùkkanā). ${ }^{23}$ In other environments, palatalization of alveolars has been more sporadic but has been facilitated or impeded by whether other aspects of a word's phonological make up have tended to draw the following vowel toward the front or the back.

In summary, I find nothing in Hausa to support either a synchronic or a historical contrast between medial short high vowels. Apparent minimal pairs like gidā vs. gùdā find an explanation in the independently required contrast in velars. Nor is there any reason to appeal to an /i/ vs. /u/ contrast to explain a word initial contrast between palatal vs. alveolar consonants. Hausa must have inherited many palatals as such, but even those that have come about through palatalization of alveolars can probably be explained by high vowels conditioned toward [i] by a following environment, with that conditioned [i] then affecting the preceding consonant.

\section{Conclusion}

Morphological palatalization, well-documented for a number of languages in the Biu-Mandara branch of the Chadic language family, must be a feature descending from an early period in the history of the family and inherited into both the BiuMandara and West Chadic branches. Though this phenomenon is not as widespread in West Chadic as it is in Biu-Mandara, it functions in one documented West Chadic language, Miya, in very much the way as it does in Biu-Mandara languages. In the Bade/Ngizim subgroup of West Chadic, one language, Duwai, exhibits certain alternations that are best explained as being remnants of an earlier, more active process of morphological palatalization. The presence of palatals and rules of palatalization in other West Chadic languages seem to involve lexicalized

23 The doublet is of interest because it suggests that the word originally had a long $\bar{u}$ in the first syllable. When the syllable was closed, the automatically shortened $\bar{u}$ became neutralized as just a "short high vowel" and underwent the regular sound changes proposed here. 
palatals and palatalization as a local phonological process. In Bole, relatively free variation between alveolars and palatals in some lexical items is reminiscent of morphological palatalization, which tends to show variable effects on individual segments. In Hausa, there is an active process that palatalizes alveolars before front vowels, but this process is generally restricted to alternations affecting specific morphemes. On the other hand, Hausa appears to have inherited palatal consonants in a large number of words where a source in phonologically conditioned palatalization is not available. Close examination of the distribution of alveolar and palatal consonants in the environment of high vowels suggests that even where a palatal appears before $i$, it is just as likely that the palatal is original and is conditioning the vowel as it is that the vowel is original and caused an erstwhile alveolar to palatalize. The substantial number of apparently underived palatals in Hausa may be a reflex of lexicalized palatals originally resulting from morphological palatalization.

\section{REFERENCES}

Gimba, Alhaji Maina. 2000. "Bole verb morphology." UCLA, PhD dissertation.

Hoffmann, Carl. 1972. "Some aspects of palatalization in Mapuda." University of Ibadan, mimeo.

Hoskison, James T. 1974. "Prosodies and verb stems in Gude." Linguistics 141:17-26.

Hoskison, James T. 1975. "Notes on the phonology of Gude." MA thesis, The Ohio State University.

Jarvis, Elizabeth. n.d. "Esquisse grammaticale du podoko." SIL Cameroon, mimeo.

Lukas, Johannes. 1968. "Nunation in afrikanischen Sprachen." Anthropos 63:97114.

Newman, Paul. 1977. "Chadic classification and reconstructions." Afroasiatic Linguistics 5(1):1-42. 
Newman, Paul. 1979. "The historical development of medial /ee/ and /oo/ in Hausa." Journal of African Languages and Linguistics 1:173-188.

Newman, Paul. 2000. The Hausa Language: An Encyclopedic Reference Grammar. New Haven: Yale University Press.

Parsons, F. W. n.d. "The vowel system of the radical in Hausa: an essay in metaphonemic analysis." SOAS, unpublished ms.

Parsons, F. W. 1970. "Is Hausa really a Chadic language? Some problems in comparative phonology." African Language Studies 11:272-288.

Schuh, Russell G. 1971. "Toward a typology of Chadic vowel and tone systems." UCLA, unpublished $\mathrm{PhD}$ qualifying paper.

Schuh, Russell G. 1973/74. "Nunation and gender in Bade." Afrika und Übersee 58:106-119.

Schuh, Russell G. 1981. "Using dialect geography to determine prehistory: A Chadic case study." Sprache und Geschichte in Afrika 3:201-250.

Schuh, Russell G. 1998. A Grammar of Miya. University of California Publications in Linguistics, Volume 130. Berkeley, Los Angeles \& London: University of California Press.

Schuh, Russell G. and Alhaji Maina Gimba. 2000a. Bole Dictionary. Electronic database, under revision.

Schuh, Russell G. and Alhaji Maina Gimba. 2000b. "Segmental phonology." Draft chapter of a grammar of Bole, in preparation.

Swackhamer, Jeanette. n.d. "Podoko phonology." SIL Cameroon, mimeo.

Department of Linguistics

[Received June 2002;

Box 951543

University of California accepted July 2002]

Los Angeles, CA 90095-1543

schuh@humnet.ucla.edu 